\title{
PENGAMBILALIHAN DAN PENUTUPAN \\ PERUSAHAAN YANG BERDAMPAK PADA PERSELISIHAN \\ PEMUTUSAN HUBUNGAN KERJA MENURUT \\ UNDANG-UNDANG NOMOR 13 TAHUN 2003 TENTANG \\ KETENAGAKERJAAN
}

\author{
Mohammad Ilyas, S.H. \\ ABSTRAK
}

\begin{abstract}
Perusahaan pada hakikatnya dibentuk untuk mencari keuntungan dan atau laba yang sebesar-besarnya, namun dalam aktivitasnya tersebut tidak dapat dihindari pula terjadinya kerugian pada perusahaan sehingga demi menjaga stabilitas perekonomian perusahaannya, pengusaha melakukan kegiatan pengambilalihan, maupun penutupan perusahaan. Adapun beberapa hal yang menjadi rumusan-rumusan masalah yaitu bagaimana perlindungan hukum terhadap buruh / pekerja ketika terjadi Perselisihan Pemutusan Hubungan Kerja (PHK) akibat pengambilalihan maupun penutupan perusahaan? dan bagaimana permasalahan dan model Penyelesaian Perselisihan Pemutusan Hubungan Kerja antara pekerja dan pengusaha akibat tindakan pengambilalihan maupun penutupan perusahaan?. Ada dua bentuk perlundungan hukum terhadap buruh / pekerja ketika terjadi Perselisihan Pemutusan Hubungan Kerja (PHK) akibat pengambilalihan maupun penutupan perusahaan, yaitu perlindungan hukum bagi pekerja / buruh atas pengusaha yang tidak bersedia melanjutkan hubungan kerja dan perlindungan hukum bagi pekerja / buruh yang tidak bersedia melanjutkan hubungan kerja. Upaya hukum yang dapat ditempuh pekerja untuk menyelesaikan perselisihan pemutusan hubungan kerja tersebut dapat melalui jalur Penyelesaian Perselisihan Pemutusan Hubungan Kerja di luar Pengadilan Hubungan Industrial (non litigasi) ini dapat dilakukan dengan penyelesaian melalui bipartit, konsiliasi Arbitrase, mediasi. Dan Penyelesaian Perselisihan Pemutusan Hubungan Kerja melalui Pengadilan Hubungan Industrial.
\end{abstract}

Kata Kunci : Pengambilalihan dan Penutupan, Perusahaan dan PHK 


\title{
TAKING OVER AND CLOSURING A COMPANIES WHICH IMPACT ON EMPLOYMENT TERMINATION DISPUTES BASED ON LAW NUMBER 13 YEAR 2003 ON EMPLOYMENT
}

\begin{abstract}
Mohammad Ilyas, S.H.
ABSTRACT

The company is essentially formed to seek benefit and/or profits as much as possible, but in its activities, it cannot be avoided also the loss of the company so that in order to maintain the stability of the company's economy, entrepreneurs make takeover activities, as well as the closure of the company. As for some matters, the formulation of the problem is how to protect the law against the workers/labors when there is a Dispute Termination of Employment (PHK) due to the takeover or closure of the company? And how are the problems and models of the Settlement of Employment Dispute Settlements between workers and employers due to takeover or closure of the company? There are two forms of legal protection to the worker/labor in the Employment Termination (PHK) resulting from the takeover or closure of the company, namely legal protection for workers/laborers against the employer who are unwilling to continue employment and legal protection for workers who are unwilling to continue work relationship. Legal remedies by which the employee may resolve the termination disputes may pass through the Termination Dispute Settlement outside the Industrial Relations Court (non litigation) may be made by settlement through bipartite, arbitration conciliation, mediation. And Termination Dispute Settlement is through Industrial Relations Court.
\end{abstract}

Keywords: Takeover and Closure, Company and Employment Termination 


\section{PENDAHULUAN}

\section{A. Latar Belakangan}

Hubungan kerja saat ini juga dikenal dengan hubungan industrial dan Perjanjian Kerja Perorangan baik untuk pekerjaan tertentu maupun waktu tertentu (PKWT) dan Perjanjian Kerja untuk waktu tidak tertentu (PKWTT) serta Perjanjian Kerja kolektif yang dibuat antara perwakilan pekerja Serikat Pekerja/ Serikat Buruh (SP/SB) dengan pengusaha atau gabungan pengusaha. Perjanjian kerja pada masa sekarang ini masih sangat diperlukan sebagai pendamping dari peraturan perundang-undangan yang berlaku karena secara umum peraturan perundang-undangan ketenagakerjaan kita belum mengatur secara terperinci tentang syaratsyarat kerja, hak dan kewajiban masing-masing pihak.

Pengertian Perjanjian Kerja merupakan hubungan antara seseorang yang bertindak sebagai pekerja atau buruh dengan seseorang yang bertindak sebagai majikan. Dalam ketentuan perjanjian kerja ada unsur wewenang untuk memerintah, artinya antara kedua belah pihak ada kedudukan yang tidak sama yang disebut sub ordinasi seperti dikemukakan Djumialdji bahwa ada pihak yang kedudukannya di atas, ada yang memerintah dan ada pihak yang kedudukannya di bawah yaitu yang diperintah ". 1

Hukum dalam bidang Ketenaga kerjaan sangat penting untuk dibentuk guna melindungi hak-hak dari pekerja atau buruh yang bekerja pada suatu perusahaan karena secara tidak langsung, pekerja/buruh tersebut telah memberikan kontribusi dalam pembangunan nasional. Seseorang dalam status dan kedudukannya bekerja pada perusahaan berhak untuk mendapatkan upah serta hak lainnya yang berkaitan dengan status dan kedudukannya sebagai pekerja pada perusahaan, dan pekerja tersebut juga memiliki kewajiban untuk memberikan prestasi baik dengan menghasilkan barang, memberikan jasa, maupun kewajiban lainnya yang berkaitan dengan status dan kedudukannya sebagai pekerja pada perusahaan tersebut. $^{2}$

\footnotetext{
${ }^{1}$ Djumialdji, F.X., Perjanjian Kerja, Edisi kedua, Cetakan Kelima, ( Jakarta : Sinar Grafika, 2012 ), halaman 18.

2 I Wayan Agus Vijayantera, Perse-lisihan Pemutusan Hubungan Kerja Sebagai Dampak Penggabungan, Peleburan, Peng-ambilalihan, Dan Penutupan Perusahaan, (Tesis : Program Studi Magister Hukum Minat Studi Hukum Bisnis
} 
Kepentingan pekerja harus diperhatikan oleh pengusaha dalam hal pengusaha melakukan pengambilalihan ataupun penutupan perusahaan, karena dengan tindakan pengusaha tersebut tidak secara otomatis membuat hubungan kerja antara perusahaan dengan pekerja menjadi berakhir. Perlu ada proses pemutusan hubungan kerja untuk mengakhiri hubungan kerja yang telah terjalin antara pihak pengusaha dan pekerja akibat tindakan pengusaha dalam melakukan pengambilalihan ataupun penutupan perusahaan.

Tindakan perusahaan dalam melakukan pengambilalihan ataupun penutupan perusahaan tidak menutup kemungkinan tindakan perusahaan tersebut dapat mengakibatkan muncul perselisihan hubungan industrial antara pekerja dan perusahaan terutama perselisihan pemutusan hubungan kerja. Secara teknis, terdapat upaya-upaya penyelesaian yang diatur sebagaimana dalam ketentuan UndangUndang Republik Indonesia No.2 Tahun 2004 tentang Penyelesaian Perselisihan Hubungan Industrial.

Fakultas Hukum Universitas Airlangga Surabaya 2016), halaman 6 .
Guna mengetahui perlindungan hukum terhadap pekerja serta upaya hukum yang dapat ditempuh oleh pekerja akibat terjadinya perselisihan hubungan industrial terutama terjadinya perselisihan pemutusan hubungan kerja akibat tindakan pengambilalihan maupun penutupan perusahaan. Berlatar belakang dari permasalahan tersebut, maka penulis tertarik untuk meneliti tentang " Pengambilalihan dan Penutupan Perusahaan yang berdampak pada Perselisihan Pemutusan Hubungan Kerja Menurut Undang-Undang No.13 Tahun 2003 tentang Ketenagakerjaan ".

\section{B. Perumusan Masalah}

Berdasarkan uraian-uraian latar belakang masalah tersebut, ada beberapa hal yang menjadi rumusanrumusan masalah, yaitu :

1) Bagaimana Perlindungan Hukum Terhadap Buruh / Pekerja Ketika Terjadi Perselisihan Pemutusan Hubungan Kerja ( PHK ) Akibat Pengambilalihan dan Penutupan Perusahaan Menurut UndangUndang No.13 Tahun 2003 tentang Ketenagakerjaan?

2) Bagaimana Permasalahan dan model Penyelesaian Perselisihan Pemutusan Hubungan Kerja 
Antara Pekerja Dan Pengusaha

Akibat Tindakan Pengambilalihan dan Penutupan Perusahaan Menurut Undang-Undang No.13 Tahun 2003 tentang Ketenagakerjaan?

\section{TINJAUAN PUSTAKA}

\section{A. Tinjauan Tentang Hubungan Kerja}

Berdasarkan Pasal 1 angka 15 Undang-Undang No.13 Tahun 2003 tentang Ketenaga kerjaan, Hubungan kerja adalah hubungan antara pengusaha dengan pekerja/buruh berdasarkan perjanjian kerja, yang mempunyai unsur pekerjaan, upah, dan perintah. Dalam Pasal 50 Undang-Undang No.13 Tahun 2003, disebutkan bahwa hubungan kerja terjadi karena adanya perjanjian kerja antara pengusaha dan pekerja/buruh. Perjanjian kerja dibuat secara tertulis atau lisan. Jadi, hubungan kerja adalah hubungan (hukum) antara pengusaha dengan buruh/pekerja berdasarkan perjanjian kerja. Dengan demikian, hubungan kerja tersebut adalah sesuatu yang abstrack, sedangkan perjanjian kerja adalah sesuatu yang konkret atau nyata. Dengan adanya perjajian kerja, akan ada ikatan antara pengusaha dan pekerja. ${ }^{3}$

Unsur-unsur perjanjian kerja yang menjadi dasar hubungan kerja sesuai dengan ketentuan Pasal 1 angka 4 Undang-Undang No.13 Tahun 2003 tentang Ketenaga kerjaan adalah :

1. Adanya pekerjaan (arbeid), adalah Adanya pekerjaan (arbeid), yaitu pekerjaan bebas sesuai dengan kesepakatan buruh dan majikan, asalkan tidak bertentangan dengan ketertiban umum, kesusilaan, dan peraturan perundang-undangan yang berlaku.

2. Dibawah perintah/gejagverhouding (maksudnya buruh melakukan pekerjaan atas perintah majikan, sehingga bersifat subordinasi), yaitu dibawah perintah (gejag verhouding), di dalam hubungan kerja kedudukan majikan adalah pemberi kerja, sehingga ia berhak dan sekaligus berkewajiban untuk memberikan perintah-perintah yang berkaitan dengan pekerjaanya.

3. Adanya upah tertentu/loan, adanya upah (loan) tertentu yang menjadi imbalan atas pekerjaan yag telah dilakukan oleh buruh.

3 Adrian Sutedi, Hukum Perburuhan, ( Jakarta : Sinar Grafika, 2009 ), halaman 45 
Pengertian upah berdasarkan

ketentuan Pasal 1 angka 30

Undang-Undang Nomor 13 Tahun 2003 adalah hak pekerja/buruh yang diterima dan dinyatakan dalam bentuk uang sebagai imbalan dari pengusaha atau pemberi kerja kepada pekerja atau buruh yang ditetapkan dan dibayarkan menurut perjanjian kerja.

4. Dalam waktu (tjid) yang ditentukan (dapat tanpa batas waktu/pensiun atau berdasarkan waktu tertentu, artinya buruh bekerja untuk waktu yang ditentukan atau untuk waktu yang tidak tertentu ${ }^{4}$.

Kesepakatan kedua belah pihak yang lazim disebut kesepakatan bagi yang mengikatkan dirinya maksudnya bahwa pihakpihak yang mengadakan perjanjian kerja harus setuju/sepakat, seiasekata mengenai hal-hal yang diperjanjikan. Apa yang dikehendaki pihak yang satu dikehendaki pihak yang lain. Pihak pekerja menerima pekerjaan yang ditawarkan, dan pihak pngusaha menerima pekerjaan tersebut untuk dipekerjakan.

\section{B. Tinjauan Tentang Pemutusan}

${ }^{4}$ Asri Wijayanti, Hukum Ketenaga kerjaan Pasca Reformasi, ( Jakarta : Sinar Grafika, 2010), halaman 37.

\section{Hubungan Kerja}

Pemutusan hubungan kerja antara buruh dengan pengusaha lazimnya dikenal dengan dengan PHK atau pengakhiran hubungan kerja, yang dapat terjadi karena telah berakhirnya waktu tertentu yang telah disepakati/diperjanjikan sebelumnya dan dapat pula terjadi karena adanya perselisihan antara buruh dan majikan, meninggalnya buruh atau karena sebab lainya.

Undang-Undang No.13 Tahun 2003 Pasal 1 angka 25 menjelaskan bahwa : " pemutusan hubungan kerja adalah pengakhiran hubungan kerja karena satu hal tertentu yang mengakibatkan berakhirnya hak dan kewajiban antara buruh/pekerja dan pengusaha ". Pemutusan kerja bagi pihak buruh dapat memberikan pengaruh psikologis, ekonomis, finansial sebab :

1. Dengan adanya pemutusan hubungan kerja, bagi buruh telah kehilangan mata pencaharian ;

2. Untuk mencari pekerjaan yang baru sebagai penggantinya, harus banyak mengeluarkan biaya (keluar masuk perusahaan, di samping biaya-biaya lain seperti pembuatan surat-surat untuk keperluan lamaran dan fotocopy surat-surat lain) ; 
3. Kehilangan biaya hidup untuk diri dan keluarganya sebelum mendapat pekerjaan yang baru sebagai penggantinya ${ }^{5}$.

Mengenai PHK secara khusus juga diatur dalam Undang-Undang No.2 Tahun 2004 tentang Penyelesaian Perselisihan Hubungan Industrial (PPHI). Dengan berlakukan Undang-Undang PPHI 2004 tersebut, Undang-Undang No.12 Tahun 1964 tentang Pemutusan Hubungan Kerja di Perusahaan Swasta dan Undang-Undang No.22 Tahun 1957 tentang Penyelesaian Perselisihan Perburuhan dinyatakan tidak berlaku lagi. Namun, untuk peraturan pelaksanaan kedua undang-undang tersebut masih tetap berlaku sepanjang tidak bertentangan dengan Undang-Undang PPHI 2004, istilah sengketa yang digunakan adalah perselisihan atau perselisihan hubungan industrial. ${ }^{6}$

Sedangkan dalam UndangUndang Ketenagakerjaan juga dijelaskan mengenai penyebab terjadinya $\mathrm{PHK}$ dengan kesalahan berat, hal tersebut dijelaskan dalam Pasal 158 Undang-Undang tentang Ketenagakerjaan. Pengusaha dapat

${ }^{5}$ Zainal Asikin, Dasar-dasar Hukum Perburuhan, Jakarta : PT. Raja Grafindo Persada, 2010 ) halaman 174

${ }^{6}$ Op.Cit., halaman 07 memutuskan hubungan kerja terhadap pekerja/buruh dengan alasan pekerja/buruh telah melakukan kesalahan berat :

1. melakukan penipuan, pencurian, atau penggelapan barang dan/ atau uang milik perusahaan ;

2. memberikan keterangan palsu sehingga merugikan perusahaan ;

3. mabuk, meminum minuman keras yang memabukkan, memakai dan/atau mengedarkan narkotika, psikotropika, dan zat adiktif lainnya ;

4. melakukan perbuatan asusila atau perjudian di lingkungan kerja ;

5. menyerang, menganiaya, mengancam, atau mengintimidasi teman sekerja atau pengusaha di lingkungan kerja ;

6. membujuk teman sekerja atau pengusaha untuk melakukan perbuatan yang bertentangan dengan peraturan perundangundangan ;

7. dengan ceroboh atau sengaja atau membiarkan dalam keadaan bahaya barang milik perusahaan yang menimbulkan kerugian bagi perusahaan ;

8. dengan ceroboh atau sengaja membiarkan teman sekerja atau pengusaha dalam keadaan bahaya di tempat kerja ; 
9. membongkar atau membocorkan rahasia perusahaan yang seharusnya dirahasiakan kecuali untuk kepentingan negara ; atau

10. melakukan perbuatan lainnya di lingkungan perusahaan yang diancam pidana penjara 5 (lima) tahun atau lebih.

\section{Tinjauan Umum}

\section{Pengambilalihan dan Penutupan Perusahaan}

Upaya efisiensi dan maksimalisasi hasil usaha dilakukan oleh pengusaha atau majikan dapat dengan tindakan pengambilalihan ataupun penutupan perusahaan. Pada saat pengusaha melakukan tindakan pengambilalihan perusahaan, apabila mengacu pada ketentuan Pasal 126 ayat (1) Undang-Undang No.40 Tahun 2007 tentang Perseroan Terbatas, pengusaha wajib untuk memperhatikan :

1. Perseroan, pemegang saham minoritas, karyawan Perseroan ;

2. kreditor dan mitra usaha lainnya dari Perseroan ; dan

3. masyarakat dan persaingan sehat dalam melakukan usaha.

Karyawan perseroan dalam hal ini disebut sebagai pekerja sebagaimana dalam huruf a tersebut wajib untuk diperhatikan kepen- tingannya. Hal ini karena pekerja merupakan bagian dari perusahaan yang berperan penting dalam menggerakkan perusahaan, meningkatkan hasil produksi, dan hal-hal yang terkait dalam memajukan perusahaan. Pada saat pengusaha melakukan tindakan pengambilalihan maupun penutupan perusahaan, tidak menutup adanya pihak-pihak yang mengajukan keberatan atas tindakan tersebut. Adapun pihakpihak yang dapat mengajukan keberatan terhadap adanya penggabungan, peleburan, dan pengambilalihan perusahaan sebagai mana dalam ketentuan UndangUndang No.40 Tahun 2007 yakni pihak pemegang saham dan kreditor.

Berdasarkan ketentuan Pasal 62 Undang-Undang No.40 Tahun 2007 tentang Perseroan Terbatas menyatakan bahwa :

1) Setiap pemegang saham berhak meminta kepada Perseroan agar sahamnya dibeli dengan harga yang wajar apabila yang bersangkutan tidak menyetujui tindakan Perseroan yang merugikan pemegang saham atau Perseroan, berupa :

a. perubahan anggaran dasar ;

b. pengalihan atau penjaminan kekayaan Perseroan yang 
mempunyai nilai lebih dari $50 \%$

( lima puluh persen ) kekayaan bersih Perseroan ; atau

c. penggabungan, peleburan, pengambilalihan, atau pemisahan.

2) Dalam hal saham yang diminta untuk dibeli sebagaimana dimaksud pada ayat (1) melebihi batas ketentuan pembelian kembali saham oleh Perseroan sebagaimana dimaksud dalam Pasal 37 ayat (1) huruf b, Perseroan wajib mengusahakan agar sisa saham dibeli oleh pihak ketiga. $^{7}$

Berdasarkan pada ketentuan pasal tersebut, pihak pemegang saham yang merasa keberatan terhadap adanya tindakan pengambilalihan perusahaan, meminta agar perusahaan tersebut membeli kembali sahamnya dengan harga yang wajar, dan apabila saham yang diminta untuk dibeli tersebut melebihi batas ketentuan pembelian kembali saham oleh perusahaan, maka pihak perusahaan akan mengusahakan agar sisa saham dibeli oleh pihak ketiga. Ketentuan ini lah yang digunakan untuk menjamin hak dari pemegang saham yang merasa dirugikan akibat tindakan perusahaan tersebut.
Perusahaan memiliki kewajiban untuk mengusahakan agar sisa saham dibeli oleh pihak ketiga sebagaimana dalam yang dijelaskan dalam ketentuan ayat (2) tersebut. Hal ini berarti pihak perusahaan yang memiliki kewajiban dalam mencari pihak ketiga yang bersedia untuk membeli sisa saham pihak pemegang saham yang belum dibeli perusahaan akibat melebihi batas ketentuan pembelian kembali saham perusahaan. Pihak pemegang saham sebagai pihak yang merasa dirugikan atas tindakan pelaku usaha yang melakukan pengambilalihan perusahaan, tidak memiliki kewajiban untuk mencari pihak ketiga yang bersedia untuk membeli atas sisa saham yang belum dibeli perusahaan.

Bentuk lain tindakan perusahaan selain penggabungan dan peleburan perusahaan yakni berupa pengambilalihan perusahaan. Pengambilalihan merupakan suatu kondisi beralihnya hak yang dimiliki oleh orang ataupun badan hukum terhadap perusahaan.

Pengertian dari pengambilalihan perusahaan dapat dijelaskan dalam beberapa peraturan hukum terkait Perseroan Terbatas yakni sebagai berikut : 
1. Pasal 1 ayat (11) Undang-Undang No.40 Tahun 2007 tentang Perseroan Terbatas menyatakan bahwa : Pengambilalihan adalah perbuatan hukum yang dilakukan oleh badan hukum atau orang perseorangan untuk mengambilalih saham Perseroan yang mengakibatkan beralihnya atas Perseroan tersebut.

2. Pasal 1 ayat (3) Peraturan Pemerintah No.27 Tahun 1998 tentang Penggabungan, Peleburan, dan Pengambilalihan Perseroan Terbatas, menyatakan : Pengambilalihan adalah perbuatan hukum yang dilakukan oleh badan hukum atau orang perseorangan untuk mengambilalih baik seluruh ataupun sebagian besar saham perseroan yang dapat mengakibatkan beralihnya pengendalian terhadap perseroan tersebut.

Berdasarkan pada beberapa pengertian mengnai pengambilalihan alihan tersebut, dapat ditafsirkan pada intinya pengambilalihan perusahaan berupa tindakan mengambilalih saham dari suatu perusahaan. Pengambilalihan saham dalam perseroan terbatas biasanya dilakukan dengan cara pelaku usaha melakukan pembelian saham dari pihak pemegang saham perseroan terbatas.

\section{Perselisihan Hubungan Industrial}

Perslisihan hubungan industrial sebagaimana tertuang dalam Pasal 1 ayat (22) Undang-Undang No.13 Tahun 2003 tentang Ketenagakerjaan bahwa : Perselisihan hubungan industrial adalah perbedaan pendapat yang mengakibatkan pertentangan antara pengusaha atau gabungan pengusaha dengan pekerja/buruh atau serikat pekerja/ serikat buruh karena adanya perselisihan mengenai hak, perselisihan kepentingan, dan perselisihan pemutusan hubungan kerja serta perselisihan antar serikat pekerja/ serikat buruh hanya dalam satu perusahaan.

Perselisihan hubungn industrial yang dibagi menjadi empat perselisihan tersebut, baik berupa perselisihan hak, kepentingan, pemutusan hubungan kerja serta perselisihan antar serikat pekerja/ serikat buruh, dalam Undang-Undang No.13 Tahun 2003 tidak memberi penjelasan mengenai 4 (empat) jenis perselisihan hubungan industrial. Keempat jenis perselisihan hubungan industrial tersebut dijelaskan dalam 
ketentuan Undang-Undang No.2 Tahun 2004 tentang Penyelesaian Perselisihan Hubungan Industrial.

Terhadap perselisihan yang terjadi diantara para pihak, dapat diselesaikan dengan cara menyelesaikan sengketa melalui jalur litigasi (pengadilan) dan non litigasi (di luar pengadilan). Penyelesaian sengketa melalui jalur litigasi pada umumnya dimulai dari Pengadilan hubungan industrial pada Pengadilan Negeri dan pada tingkat Mahkamah Agung. Penyelesaian sengketa perdata di pengadilan umumnya didasarkan terhadap :

1. Adanya wanprestasi atau ingkar janji salah satu pihak, dimana untuk gugatan harus didasarkan pada adanya hubungan kontraktual (privity of contract) di antara para pihak (penggugat dan tergugat) ;

2. Adanya perbuatan melanggar hukum (onrechtmatigedaad), dimana dalam gugatan berdasarkan perbuatan melanggar hukum tidak perlu didahului adanya hubungan kontraktual diantara para pihak, namun yang paling elementer adalah adanya perbuatan yang merugikan pihak lain serta terdapat hubungan kausal antara perbuatan dengan kerugian yang ditimbulkan sebagai akibat kesalahannya ${ }^{7}$.

Pasal 1 ayat (10) UndangUndang Republik Indonesia Nomor 30 Tahun 1999 tentang Arbitrase dan Alternatif Penyelesaian Sengketa menyatakan : Alternatif Penyelesaian Sengketa adalah lembaga penyelesaian sengketa atau beda pendapat melalui prosedur yang disepakati para pihak, yakni penyelesaian di luar pengadilan dengan cara konsultasi, negosiasi, mediasi, konsiliasi, atau penilaian ahli.

\section{HASIL PENELITIAN DAN}

\section{PEMBAHASAN}

A. Perlindungan Hukum Terhadap Buruh / Pekerja Ketika Terjadi Perselisihan Pemutusan

\section{Hubungan Kerja ( PHK )}

Perlindungan hukum terhadap pekerja merupakan suatu bentuk perlindungan terhadap hak serta kepentingan pekerja yang diatur melalui ketentuan hukum. Ketika pelaku usaha melakukan tindakan pengambilalihan perusahaan, tidak menutup kemungkinan akan terjadinya restrukturisasi terkait posisi pekerja, mutasi maupun demosi

\footnotetext{
Agus Yudha Hernoko, Hukum Perjanjian Azas Proporsionalitas dalam Kontrak Komersial, ( Yogyakarta : Laks Bang Mediatama, 2008 ), halaman 278 .
} 
terhadap pekerja, serta terjadi perubahan perjanjian kerja yang berdampak pada pengurangan maupun penambahan hak dan/atau kewajiban bagi pekerja yang bekerja dalam perusahaan. Dampak dari penutupan perusahaan yakni terjadinya pemutusan hubungan kerja terhadap pekerja di perusahaan. Perlindungan hukum sangat diperlukan bagi pekerja dengan adanya pemutusan hubungan kerja terhadap dirinya akibat pelaku usaha melakukan pengambilalihan maupun penutupan perusahaan.

1) Perlindungan hukum bagi pekerja / buruh atas pengusaha yang tidak bersedia melanjutkan hubungan kerja

Pada ketentuan Pasal 163 ayat (2) Undang-Undang No.13 Tahun 2003 tentang Ketenagakerjaan kondisi pemutusan hubungan kerja terjadi ketika terjadi perubahan status dan pengusaha tidak bersedia menerima pekerja untuk bekerja di perusahaannya. Pada dasarnya pemutusan hubungan kerja terhadap pekerja sangat tidak dianjurkan bagi pelaku usaha, namun dikarenakan hal-hal yang berkaitan dengan perekonomian perusahaan yang menjadi salah satu alasan bagi pelaku usaha untuk tidak dapat menghindari adanya pemutusan hubungan kerja terhadap pekerja yang bekerja di dalam perusahaannya. Pemutusan hubungan kerja yang terjadi agar tidak semena-mena dilakukan oleh pelaku usaha terhadap pekerjanya, maka sangat perlu adanya perlindungan hukum terhadap hak-hak pekerja. Pelaku usaha wajib memperhatikan pihakpihak terutama pihak pekerja yang bekerja pada perusahaannya ketika melakukan tindakan tersebut. ${ }^{8}$

Pelaku usaha baru yang mengambilalih perusahaan tidak dibenarkan melakukan pemutusan hubungan kerja terhadap pekerja tanpa adanya alasan yang jelas. Pada ketentuan Undang-Undang No.13 Tahun 2003 tentang Ketenagakerjaan, pengaturan mengenai pemutusan hubungan kerja yang dilakukan oleh pengusaha dengan kondisi pengusaha tidak bersedia menerima pekerja di perusahaannya ini tidak terdapat pengaturannya karena dengan beralihnya kendali atas perusahaan atau berubahnya manajemen perusahaan.

2) Perlindungan hukum bagi pekerja / buruh yang tidak bersedia melanjutkan hubungan kerja

\footnotetext{
${ }^{8}$ I Wayan Agus Vijayantera, Op.Cit., halaman 63.
} 
Pekerja memiliki hak untuk tidak melanjutkan hubungan kerja dengan pengusaha ketika pengusaha tersebut melakukan pengambilalihan maupun pemisahan perusahaan. Pemutusan hubungan kerja merupakan kondisi yang tidak hanya terjadi karena pengusaha tidak bersedia melanjutkan hubungan kerja dengan pekerja, melainkan pekerja tersebut pula memiliki hak untuk tidak bersedia melanjutkan hubungan kerja dengan pengusaha.

Pasal 163 ayat (1) UndangUndang No.13 Tahun 2003 tentang Ketenagakerjaan menyatakan : " adapun yang menjadi sebab pemutusan hubungan kerja yakni karena terjadi perubahan status, penggabungan, peleburan, atau perubahan kepemilikan perusahaan, dan pekerja tersebut tidak bersedia melanjutkan hubungan kerjanya lagi dengan pengusaha ". Makna perubahan kepemilikan perusahaan dalam ketentuan pasal tersebut dapat dimaknai sebagai bentuk dari pengambilalihan perusahaan karena akibat hukum dari pengambilalihan perusahaan yakni terjadinya perubahan kepemilikan atas perusahaan tersebut. $^{9}$
Tindakan pengambilalihan perusahaan yang dilakukan pengusaha dapat mengakibatkan adanya perubahan perjanjian kerja yang berupa penambahan atau pengurangan hak dan kewajiban pekerja, ataupun pembuatan perjanjian kerja baru yang mengakibatkan terjadinya perubahan masa kerja pekerja. Atas akibat yang ditimbulkan dari tindakan pngambilalihan perusahaan tersebut, maka pekerja memiliki hak untuk tidak bersedia melanjutkan hubungan kerja dengan pengusaha tersebut.

Sebagaimana ketentuan Pasal 163 ayat (1) Undang-Undang No.13 Tahun 2003 tentang Ketenagakerjaan, pihak pengusaha dapat melakukan pemutusan hubungan kerja apabila pekerja tersebut tidak bersedia melanjutkan hubungan kerja. Tindakan pengambilalihan perusahaan dalam hal tidak terjadi perubahan terhadap perjanjian kerja, namun jika pekerja tetap tidak bersedia melanjutkan hubungan kerja dengan pengusaha maka pengusaha dapat melakukan pemutusan hubungan kerja terhadap pekerja dengan dasar ketentuan Pasal 163 ayat (1) Undang-Undang No.13 Tahun 2003 tentang Ketenagakerjaan tersebut. 
B. Permasalahan dan model maka tahap-tahap penyelesaian

Penyelesaian Perselisihan

Pemutusan Hubungan Kerja

Antara Pekerja Dan Pengusaha

Menurut pasal 1 angka 4

Undang-Undang No.2 Tahun 2004 perselisihan pemutusan hubungan kerja adalah perselisihan yang timbul karena tidak adanya kesesuaian pendapat mengenai pengakhiran hubungan kerja yang dilakukan oleh salah satu pihak. Rumusan pasal ini netral, hal ini tampak dari frasa " yang dilakukan oleh salah satu pihak ", ini berarti bisa pengusaha atau buruh. Hal yang sering terjadi adalah pemutusan hubungan kerja yang dilakukan oleh pengusaha.

1) Penyelesaian Perselisihan Pemutusan Hubungan Kerja di luar Pengadilan Hubungan Industrial

a) Penyelesaian melalui bipartit

Perundingan bipartit adalah perundingan antara buruh atau serikat buruh dengan pengusaha untuk menyelesaikan perselisihan hubungan industrial. Semua jenis perselisihan hubungan industrial dapat diselesaikan lewat perundingan bipartit. Undang-Undang No.2 Tahun 2004 mewajibkan ada tahap perundingan bipartit untuk semua jenis perselisihan hubungan industrial. Jika tahap ini tidak ada, perselisihan hubungan industrial berikutnya tidak dapat ditempuh.

b) Penyelesaian melalui konsiliasi

Di dalam 4 ayat (1) UndangUndang No.2 Tahun 2004 ditegaskan bahwa jika perundingan bipartit gagal, maka salah satu pihak atau kedua belah pihak mencacatkan perselisihannya kepada instansi yang bertanggungjawab di bidang ketenagakerjaan setempat dengan melampirkan bukti bahwa upayaupaya penyelesaian melalui perundingan bipartit telah dilakukan. Setelah menerima pencatatan dari salah satu pihak atau kedua belah pihak, instansi yang bertanggung jawab di bidang ketenagakerjaan wajib menawari para pihak untuk menyepakati memilih penyelesaian melalui konsiliasi atau arbitrase. Proposisi ini melahirkan kesimpulan bahwa menurut Undang-Undang No.2 Tahun 2004 lembaga konsiliasi maupun arbitrase merupakan penyelesaian sukarela berdasarkan kehendak para pihak.

c) Penyelesaian melalui Arbitrase

Arbitrase hubungan industrial adalah penyelesaian perselisihan kepentingan dan penyelesaian perselsihan antar serikat buruh hanya dalam satu perusahaan di luar 
Pengadilan Hubungan Industrial melalui kesepakatan tertulis dari para pihak yang berselisih untuk menyerahkan penyelesaian perselisihan kepada arbiter yang putusannya mengikat para pihak dan bersifat final. Tidak ada alasan ilmiah yang dapat mendukung perselisihan hak dan perselisihan pemutusan hubungan kerja tidak dapat diselesaikan lewat lembaga arbitrase. Secara historis lembaga arbitrase justru terfokus pada penyelesaian perselisihan hak di antara para pedagang atau para pelaku usaha di dalam lalu-lintas ekonomi. Tarikmenarik kepentingan mengalahkan pertimbangan ilmiah. Justru lembaga mediasi yang di dalamnya ada unsur pemerintah diberi kewenangan untuk menyelesaikan seluruh jenis perselisihan hubungan industrial.

d) Penyelesaian melalui mediasi

Mediasi hubungan industrial adalah penyelesaian perselisihan hak, perselisihan kepentingan, perselisihan pemutusan hubungan industrial, dan penylesaian perselihan hanya dalam satu perusahaan melalui musyawarah yang ditengahi oleh seorang atau lebih mediator yang netral. Rumusan ini menunjukkan bahwa lembaga mediasi dapat menyelesaikan seluruh jenis perselisihan hubungan industrial.

2) Penyelesaian Perselisihan

Pemutusan Hubungan Kerja melalui Pengadilan Hubungan Industrial

Pengadilan Hubungn Industrial adalah pengadilan khusus yang dibentuk di lingkungan pengadilan negeri yang berwenang memeriksa, mengadili dan memberi putusan terhadap perselisihan hubungan industrial. Rumusan ini menunjukkan bahwa semua jenis perselisihan hubungan industrial dapat diselesaikan lewat Pengadilan Hubungan Industrial. Pasal 56 Undang-Undang No.2 Tahun 2004 menegaskan bahwa Pengadilan Hubungan Industrial bertugas dan berwenang memeriksa dan memutus :

1. ditingkat pertama mengenai perselisihan hak ;

2. ditingkat pertama dan terakhir dalam perselisihan kepentingan ;

3. ditingkat pertama mengenai perselisihan pemutusan hubungan kerja; dan

4. ditingkat pertama dan terakhir mengenai perselisihan antara serikat buruh.

Untuk dua jenis perselisisihan, yaitu perselisihan hak dan perselisihan pemutusan hubungan kerja 
ada upaya hukum, yaitu upaya hukum kasasi. Untuk dua perselisihan, yaitu perselisihan kepentingan dan perselisihan antar serikat buruh tidak ada upaya hukum.

Penyelesaian perselisihan hak dan perselisihan pemutusan hubungan kerja pada Mahkamah Agung selambat-lambatnya 30 hari terhitung sejak tanggal penerimaan permohonan kasasi. Ketentuan ini merupakan perwujudan asas cepat peradilan. Di dalam praktik batas waktu ini amat sulit dipenuhi, karena tumpukan perkara di Mahkamah Agung. Pasal 57 Undang-Undang No.2 Tahun 2004 menegaskan bahwa hukum acara yang berlaku pada Pengadilan Hubungan Industrial adalah hukum acara perdata yang berlaku pada pengadilan dalam lingkungan peradilan umum, kecuali yang diatur secara khusus dalam undang-undang ini.

Proses beracara pada Pengadilan Hubungan Industrial tidak mengenal upaya hukum banding, sehingga terhadap pihak yang keberatan dengan Putusan Pengadilan Hubungan Industrial terkait permasalahan perselisihan hak dan perselisihan pemutusan hubungan kerja, sebagaimana dalam ketentuan Pasal 110 dan Pasal 111 dalam Undang-Undang No.2 Tahun 2004, salah satu pihak atau para pihak dapat diajukan upaya hukum kasasi kepada Mahkamah Agung melalui Sub Kepaniteraan Pengadilan Hubungan Industrial pada Pengadilan Negeri setempat selambat-lambatnya 14 ( empat belas ) hari kerja dengan ketentuan sebagai berikut :

1. bagi pihak yang hadir, terhitung sejak putusan dibacakan dalam sidang majelis hakim ;

2. bagi pihak yang tidak hadir, terhitung sejak tanggal menerima pemberitahuan putusan.

Pada Pengadilan Negeri pada umumnya dalam hal permasalahan perdata, sebagaimana dengan dikeluarkannya. Penyelesaian sengketa perdata melalui Pengadilan Negeri pada umumnya dipandang perlu untuk melakukan mediasi di Pengadilan, namun dalam Pasal 4 Peraturan Mahkamah Agung No.1 Tahun 2008, mediasi di Pengadilan dikecualikan terhadap perkara yang diselesaikan melalui Pengadilan Niaga, Pengadilan Hubungan Industrial, keberatan atas Putusan Badan Penyelesaian Sengketa Konsumen, dan keberatan atas Putusan Komisi Pengawas Persaingan Usaha.

Berdasarkan ketentuan tersebut, maka dalam permasalahan perselisihan hubungan industrial, 
mediasi yang dilakukan oleh para pihak dengan pihak mediator yang berwenang dalam Undang-Undang No.2 Tahun 2004 sebagai penengah, mediasi tersebut sudah dipandang cukup untuk dilakukan dan tidak perlu lagi dilakukan upaya mediasi di Pengadilan Hubungan Industrial. Berkaitan dalam hal gugatan diajukan ke Pengadilan Hubungan Industrial tanpa dilampiri risalah penyelesaian melalui mediasi atau konsiliasi, ataupun gugatan diajukan tanpa dilakukan upaya mediasi atau konsiliasi sebelumnya, maka sebagaimana dalam ketentuan Pasal 83 Undang-Undang No.2 Tahun 2004, Hakim Pengadilan Hubungan Industrial wajib mengembalikan gugatan kepada penggugat. Pemeriksaan isi gugatan (dismissal process) sebenarnya hanya dikenal dalam beracara di Pengadilan Tata Usaha Negara (PTUN), tetapi pemeriksaan sepert ini juga dilakukan di Pengadilan Hubungan Industrial sebagai kekhususan dalam beracara $^{10}$.

Gugatan perseisihan hubungan industrial sebagaimana dalam Pasal 81 Undang-Undang No.2 Tahun 2004, diajukan oleh pihak penggugat

\footnotetext{
10 Abdul Khakim, Dasar-Dasar Hukum Ketenagakerjaan Indonesia, (Bandung : Citra Aditya Bakti, 2014 ), halaman 266.
}

ke Pengadilan Hubungan Industrial pada Pengadilan Negeri yang daerah hukumnya meliputi tempat pekerja / buruh bekerja. Berkaitan dengan gugatan yang diajukan, penggugat memiliki hak untuk mencabut gugatannya. Penggugat sewaktuwaktu dapat mencabut gugatannya sebelum tergugat memberikan jawaban, kemudian apabila tergugat sudah memberikan jawaban, pencabutan gugatan oleh penggugat akan dikabulkan oleh Pengadilan Hubungan Industrial apabila disetujui tergugat ${ }^{11}$.

\section{PENUTUP}

\section{A. Kesimpulan}

1. Ada dua bentuk perlundungan hukum terhadap buruh/pekerja ketika terjadi Perselisihan $\mathrm{Pe}$ mutusan Hubungan Kerja (PHK) akibat pengambilalihan maupun penutupan perusahaan, yaitu :

a) Perlindungan hukum bagi pekerja / buruh atas pengusaha yang tidak bersedia melanjutkan hubungan kerja. Hak pekerja yang dilindungi di dalam ketentuan Pasal 163 Undang-Undang Republik

${ }^{11}$ Abdul Rachmad Budiono, Hukum Perburuhan, ( Jakarta : Indeks Permata Puri Media, 2009 ), halaman 132. 
Indonesia Nomor 13 Tahun 2003 tentang Ketenagakerjaan, bagi pengusaha yang mengambilalih perusahaan apabila telah sewenangwenang melakukan pemutusan hubungan kerja terhadap pekerja tanpa adanya alasan yang jelas, maka sesuai dalam ketentuan Pasal 170 Undang-Undang Republik Indonesia Nomor 13 Tahun 2003 tentang Ketenagakerjaan.

b) Perlindungan hukum bagi pekerja / buruh yang tidak bersedia melanjutkan hubungan kerja. Sebagaimana ketentuan Pasal 163 ayat (1) UndangUndang Republik Indonesia Nomor 13 Tahun 2003 tentang Ketenagakerjaan, pihak pengusaha dapat melakukan pemutusan hubungan kerja apabila pekerja tersebut tidak bersedia melanjutkan hubungan kerja.

2. Upaya hukum yang dapat ditempuh pekerja untuk menyelesaikan perselisihan pemutusan hubungan kerja tersebut dapat melalui jalur :

a) Penyelesaian Perselisihan Pemutusan Hubungan Kerja di luar Pengadilan Hubungan
Industrial (non litigasi) ini dapat dilakukan dengan penyelesaian melalui bipartit, konsiliasi Arbitrase, dan mediasi.

b) Penyelesaian Perselisihan Pemutusan Hubungan Kerja melalui Pengadilan Hubungan Industrial. Pasal 57 UndangUndang Nomor 2 Tahun 2004 menegaskan bahwa hukum acara yang berlaku pada Pengadilan Hubungan Industrial adalah hukum acara perdata yang berlaku pada pengadilan dalam lingkungan peradilan umum, kecuali yang diatur secara khusus dalam undang-undang ini.

\section{B. Saran}

1. Bagi Pemerintah

Undang-Undang Nomor 13 Tahun 2003 tentang Ketenaga Kerjaan telah banyak diajukan judicial review di Mahkamah Konstitusi, dengan azas cepat dan murah maka di dalam penyelesaian perselisihan hubungan industrial tidak dikenal lembaga banding, hanya dikenal lembaga kasasi. Jika Pengadilan Hubungan Industrial memutus perselisihan hak atau perselisihan pemutusan hubungan kerja, maka pihak yang tidak puas atas putusan 
tersebut dapat mengajukan kasasi ke Mahkamah Agung.

2. Bagi Masyarakat / Pekerja

Pekerja agar lebih bisa meningkatkan kompetensinya terutama pengetahuan hak dasar pekerja yang diatur dalam undangundang ke tenaga kerjaan, hal ini agar lebih mengetahui tentang hak dan kewajibannya Pekerja juga bisa membentuk serikat pekerja ditingkat perusahaan sebagai wadah untuk memperjuangkan hak-hak para anggotanya.

3. Bagi Pengusaha

Pengusaha sebagai mitra pemerintah dalam menggerakkan sektor ekonomi terutama penyediaan lapangan kerja agar mengambil peran lebih aktif dengan mengefektifkan lembaga lembaga yang ada seperti lembaga kerjasama Bipartite tingkat perusahaan sehingga permasalahan yang timbul seperti pengambilihan dan penutupan perusahaan bisa diselesaikan tanpa merugikan salah satu pihak.

DAFTAR PUSTAKA

Buku
Asikin, Zainal. Dasar-dasar Hukum Perburuhan, Jakarta : PT. Raja Grafindo Persada, 2010.

Budiono, Abdul Rachmad. Hukum Perburuhan, Jakarta : Indeks Permata Puri Media, 2009.

F.X., Djumialdji. Perjanjian Kerja, Edisi kedua, Cetakan Kelima. Jakarta : Sinar Grafika, 2012.

Hernoko, Agus Yudha. Hukum Perjanjian Azas Proporsionalitas dalam Kontrak Komersial, Yogyakarta : LaksBang Mediatama, 2008.

Khakim, Abdul. Dasar-Dasar Hukum Ketenagakerjaan Indonesia, Bandung : Citra Aditya Bakti, 2014.

Sutedi, Adrian. Hukum Perburuhan, Jakarta : Sinar Grafika, 2011.

Vijayantera, I Wayan Agus. Perselisihan Pemutusan Hubungan Kerja Sebagai Dampak Penggabungan, Peleburan, Pengambilalihan, Dan Penutupan Perusahaan, (Tesis : Program Studi Magister Hukum Minat Studi Hukum 
Bisnis Fakultas Hukum Undang-Undang Republik Indonesia Universitas Airlangga Surabaya Nomor 30 Tahun 1999 tentang 2016).

Arbitrase dan Alternatif Penyelesaian Sengketa.

Wijayanti, Asri. Hukum Ketenagakerjaan Pasca Reformasi, Jakarta : Sinar Grafika, 2014.

Undang-Undang Republik Indonesia Nomor 40 Tahun 2007 tentang Perseroan Terbatas.

\section{Peraturan Perundangan}

Keputusan Menteri No. Kep78/MEN/2001 tentang Perubahan Atas Beberapa Pasal Keputusan Menteri Tenaga Kerja Republik Indonesia No. Kep-150/MEN/2000 tentang Penyelesaian Pemutusan Hubungan Kerja dan Penetapan Ulang Uang Pesangon, Uang Penghargaan Masa Bakti, dan Ganti Kerugian di Perusahaan, Jakarta : Depnaker, 2001.

Undang-Undang Nomor 2 Tahun 2004 tentang Penyelesaian Perselisihan Hubungan Industrial.

Undang-Undang Republik Indonesia Nomor 13 Tahun 2003 tentang Ketenagakerjaan. 